\title{
Online Dispute Resolution and the Form of an Arbitration Agreement
}

Przemystaw Polański1 <polanski@kozminski.edu.pl> WARSZAWA, Poland

Jacek Gotaczyński² <jacek.golaczynski@uwr.edu.pl> WROCEAW, Poland

\section{Introduction}

ODR or online dispute resolution systems could become the cornerstone of the next incarnation of e-commerce revolution. In the offline world it takes various forms, but the lessons from the past are rarely a blueprint in the online world. Online arbitrage is about settling a dispute in a way similar to a traditional court. The decision of arbiters is binding upon the parties and is enforceable, although courts may overrule the decision, if challenged. Mediation is the process of resolving issues between parties with the assistance of a third party, which helps to find a solution to the problem. Conciliation method, on the other hand, requires appointment of an expert to propose a solution to the dispute between the parties.

It is natural to expect the development of such services with the growth of electronic commerce. Developing information systems for online, outof-court resolution of disputes over illegal content on the Internet has several advantages. It may help to speed up proceedings in general and modernize the judiciary by creating state-independent online dispute resolution systems. Latest legal developments on the EU level seem to expect the provision of such services by online service providers. It seems that such an approach is necessary also due to the changing expectations of the young generation of residents of our country, brought up in the era of ubiquitous Internet. This approach is also supported by the COVID-19 pandemic, which has accelerated the transformation of the Polish economy and administration to the digital age.

1 Author of Part I.

2 Author of Part II. 
It is worth mentioning here that although out-of-court dispute resolution encounters cultural barriers and is breaking through with great difficulty, Poland is the first place in Europe, and the second after Japan, where an electronic court for blockchain technology disputes has been launched. The blockchain arbitration court was established at the Polish Chamber of Commerce for Blockchain and New Technologies and its main goal is to "provide an efficient, fast and industry-specific way of binding dispute resolution".

In this article we are going to present a challenge of solving disputes in modern Internet era relying on online, out-of-court dispute resolution mechanisms rather than traditional court systems. Modern challenges require modern solutions and a sheer volume of illegal or dubious content in cyberspace requires a more decisive action from international community, policymakers as well as nation states.

Out-of-court dispute settlement can be also categorized as the so-called alternative dispute resolution (ADR) ${ }^{3}$. Initially, the ADR movement was referred to as "alternative forms of dispute resolution", "out of court settlement techniques", "new voluntary mechanisms of resolving dispute" 4 . One of the characteristics of alternative dispute resolution methods is that they depart from absolute application of the provisions pertaining to a specific normative system in favor of equitable forms of resolving conflict between the parties. What is important in arbitration is the greater influence on the proceedings enjoyed by the parties if compared to state court proceedings (e.g. in the selection of arbitrators, methods of submitting and receiving evidence, etc.). ${ }^{5}$ Legal scholars assume that the concept of "alternative forms of dispute resolution" can be defined in three ways:

As forms of court proceedings, which, however, are alternative also to traditional court proceedings, i.e. an alternative to contentious proceedings will be non-contentious proceedings;

3 Karol Weitz and Katarzyna Gajda-Roszczenialska, 'Alternatywne metody rozwiązywania sporów ze szczególnym uwzględnieniem mediacji' in Andrzej Torbus (ed) Mediacja w sprawach gospodarczych. Praktyka-teoria-perspektywy (Ministerstwo Gospodarki Departament Doskonalenia Regulacji Gospodarczych 2015) 13.

4 Andrzej Kobyrski, Alternatywne rozwiazywanie sporów w USA. Studium teoretycznoprawne (Wydaw. UMCS 1993) 10; zob. także Aneta Arkuszewska, Informatyzacja postepowania arbitrażowego (Wolters Kluwer 2019) 50.

5 Aneta Jakubiak-Mirończuk, 'Zmiany zachodzące w charakterze form alternatywnego rozwiązywania sporów sądowych rozwój idei „zarządzania sporem”, (2008) 4 ADR. Arbitraż i Mediacja 12 ff. 
As forms of court proceedings, which, however, do not have adjudicatory character, e.g. mediation, settlement call, conciliation etc.

As all other extrajudicial forms regulated outside of state institutions competent to resolve disputes, conflicts between parties, but which are related to judicial activity, such as arbitration ${ }^{6}$.

Ultimately, it can be concluded that ADR is a method of dispute resolution alternative to courts (proceedings before state courts), conducted with the participation of a neutral, impartial party, which also includes arbitration. ODR is a subset of ADR methods that rely on Internet technologies to achieve similar goals. In the first part, written by P. Polański, the notion of online dispute resolution will be presented outlining an already functioning, early model of such regulatory mechanisms established on the EU level. In the second part, written by J. Gołaczyński, a detailed analysis of an arbitration agreement and its electronic form under Polish law will be analysed.

\section{Part I. Online Dispute Resolution}

\section{Background}

A flood of illegal content, including in particular hate speech and defamation, as well as other forms of law violations in Poland has already become a fact. ${ }^{7}$ This phenomenon only deepens the division of society caused by the results of the political elections. It will also come as no surprise that this is not just a problem in Poland, but to a greater or lesser extent around the world. The Polish Ministry of Digitalisation has already taken the first, very modest but noteworthy steps in this regard, formulating key questions as part of the consultation on the European Commission's Re-

6 Lech Morawski, Gtówne problemy wspótczesnej filozofii prawa. Prawo w toku przemian (PWN 2000) $228 \mathrm{ff}$; Łukasz Błaszczak, 'Mediacja a inne alternatywne formy rozwiazywania sporów (wybrane zagadnienia)' (2012) 2 ADR. Arbitraż i Mediacja 14.

7 The article is a result of the NCN grant nr 2014/15/B/HS5/03138 titled "Fighting illegal and harmful content on the Internet" as well as the NCN grant nr 2016/22/E/HS5/00434 "Ensuring web accessibility in accordance with national and international law as well as WCAG 2.0 guidelines." The idea described in the above article is being currently implemented practically thanks to the NCBiR grant nr 274091 "System for dispute resolution concerning illegal speech in cyberspace (eletronic arbitrage)" as part of the Tango Project led by prof. ALK dr hab. P. Polański. 
commendations on combating illegal content on the Internet, including "how should a model for out-of-court dispute resolution function?"8

The current legal situation places online intermediaries such as website administrators in the role of judges who must make decisions regarding the removal of a particular post or file of a website user. Privatisation of justice leads to the chilling effect on speech, promoting removal or blocking of potentially dangerous content just in case. This may lead to the erosion of the protection of civil liberties guaranteed by Polish and European law and burdens the intermediaries themselves with costs and administrative duties.

One of the solutions is to streamline the operation of courts, another of administrative bodies, in order to provide users with the maximum level of protection of their rights. Taking into account, however, the current burden on courts, it is highly unlikely that developing specialized courts would help to swiftly adjudicate disputes in cyberspace.

Instead, it is proposed to create a model of removal of unlawful content by arbitration bodies independent of content providers (e-arbitration) - a form of ODR or online dispute resolution. These still novel types of information society services can be encountered mainly in a traditional world of legal dispute settlement, although the Domain Name dispute resolution mechanism operated by ICANN ${ }^{9}$ could be regarded as a frontrunner of such cyber-mechanisms in an area where conflicts frequently arise.

8 The European Commission has set the online community to understand the main regulatory challenges in this area, see $<$ https://www.gov.pl/cyfryzacja/konsultacje-z alecen-komisji-europejskiej-dotyczacego-walki-z-bezprawnymi-tresciami-w-internec ie> accessed 5 December 2018.

1. "How should the actions taken by hosting providers to effectively combat illegal content on the Internet, affect the exclusion of their liability (Article 14 of Directive 2000/31/EC)?

2) How should the conditions and criteria for recognition of trusted flaggers be defined by hosting providers in order to achieve a plurality of entities?

3. if there is illegal content on the Internet, is it possible to protect it effectively if it is reported anonymously and at what stage should it be reported? How to prevent abuse of reporting?

4) How should a model for out-of-court dispute resolution work?

What are the EC recommendations (in addition to those mentioned in the above recommendation) that should be taken up by hosting providers in order to effectively fight illegal content on the Internet?

6. what is the most convenient form of collecting reports on notifications and decisions of hosting providers on illegal content on the Internet?

9 <https://www.icann.org/resources/pages/dndr-2012-02-25-en> accessed 20 July 2021. 
Online Dispute Resolution is a form of ADR (ang. Alternative Dispute Resolution) where a quarrel is settled out-of-court or without a judge. ${ }^{10}$ It make take a form of an arbitrage, mediation or conciliation but other modes are also possible. Typically, parties to the dispute have a greater freedom with respect to selection of arbiters, mediators or conciliators as well as the evidentiary rules and the proceedings usually are shorter and less expensive than traditional court adjudication. It is of particular value in the context of potentially large volume, low-cost dispute characteristics of disputants in modern cyberspace.

ODR has many additional advantages, ranging from removing from large and medium-sized entities the difficult responsibility of deciding what is lawful and what is not - to strengthening the fundamental rights of natural and legal persons in cyberspace. Furthermore, quasi-judicial bodies, independent from national states are also a direct reference to medieval arbitration courts resolving disputes between entrepreneurs based on lex mercatoria - trade customs - whose greatest advantage was speed.

The European Union already has some experience in setting up Internet-based out-of-courts systems. Already in 2013, Regulation 524/2013 on ODR in consumer disputes was adopted ${ }^{11}$, which led to the creation of the first electronic arbitration in the European Union. Recital 8 of the Regulation stresses that "ODR offers the possibility of simple, effective, fast and low-cost out-of-court resolution of disputes arising from online transactions. However, there is currently a lack of mechanisms that allow consumers and traders to resolve such disputes by electronic means; this works to the detriment of consumers, constitutes an obstacle to cross-border online transactions in particular, and creates an uneven playing field for traders and consequently hinders the overall development of online commerce."

The new platform was developed and is being used by the EU citizens in their local languages. However, the architecture is not based on the idea of centralised, online dispute resolution website, but is outsourced to national bodies settling a dispute. Despite a significant growth in the number of complaints, reaching an average of 2000 cases per month ${ }^{12}$, the statistics

10 germ. Alternative Streibeiegungm, French: le reglement extajudiciaire des litiges).

11 Regulation (EU) No 524/2013 of the European Parliament and of the Council of 21 May 2013 on online dispute resolution for consumer disputes and amending Regulation (EC) No 2006/2004 and Directive 2009/22/EC [2013] OJ L165/1-12 (Regulation on consumer ODR).

$12<$ https://ec.europa.eu/consumers/odr/resources/public2/documents/trader_info_st ats/ODR_Trader_Info_stat_EN.pdf> accessed 20 July 2021. 
have not been updated for more than three years, raising questions as to its accuracy. Although the ODR consumer disputes platform in the EU has not brought about any major breakthrough in the number of cases recognized, it has laid the foundations for upcoming developments.

The situation may fundamentally change with undergoing legislative efforts to introduce new rules to combat unlawful online content. The European Commission's draft Regulation of 15 December 2021 on the Single Market for Digital Services ${ }^{13}$ (Digital Services Act), which is intended to repeal Articles 12-15 of the E-Commerce Directive, envisages establishment of an online dispute resolution system.

The introduction of mandatory mechanism for online providers may drastically improve the situation of people whose content or accounts had been blocked by the platform provider. Online traders operating on a larger scale will both have to establish an internal dispute resolution system (Article 17 of DSA), and users of information society services will be entitled to submit their dispute to dispute resolution by providers of electronic arbitration services established and certified in Member States (Article 18 of DSA ).

The DSA does not seek to replace the right to a court with the right to electronic out-of-court dispute settlement, but only complements this right. Hence, the idea of incorporating ODR as a new mechanism for online dispute resolution is to be welcomed, refreshing the optional call for Member States to develop such solutions expressed in Article 17 of the E-Commerce Directive, which has never materialised in practice.

\section{Requirements for ODR}

It is particularly important to set out the general principles expressed in Article 5(1) of the DSA. "The ODR platform shall be user-friendly. The development, operation and maintenance of the ODR platform shall ensure that the privacy of its users is respected from the design stage ('privacy by design') and that the ODR platform is accessible and usable by all, including vulnerable users ('design for all'), as far as possible)."

There are two principles expressed in the aforementioned provision. Firstly, it is important to note the need to create an ODR platform based

13 Proposal for a Regulation of the European Parliament and of the Council on a Single Market For Digital Services (Digital Services Act) and amending Directive 2000/31/EC, COM/2020/825 final 
on the privacy standard introduced by the GDPR ${ }^{14}$, especially privacy by design and privacy by default. These principles may be challenging to implement in the context of a dispute management as it will require managing sensitive data originating from many users, especially comments revealing ethnic origin or health status. Transfer of data to third countries, particularly the USA, may also turned out the be problematic.

Secondly, the ODR platform should be accessible to everyone, including people with special needs. This requires that the platform be created taking into account the principles developed from the bottom up by the international community, i.e. the WCAG 2.1 principles (Web Content Accessibility Guidelines). The aforementioned guidelines require that interactive elements, such as forms are accessible to blind people as well as people with other types of limitations.

Apart from the privacy and accessibility-friendly requirements, the draft of DSA regulation outlines general organisational obligations for the operator of a platform. The dispute resolution service provider should (1) be independent, (2) have the knowledge and skills to resolve disputes related to unlawful content, (3) provide a fast, low-cost and impartial process (4) operate under procedural rules that are transparent and fair, and (5) provide easy access to the functionalities offered by the dispute resolution platform. The fulfilment of the above requirements is to be confirmed by an appropriate certificate issued by the national Digital Services Coordinator envisioned by the project.

Theoretically, there is nothing to prevent such a dispute resolution system from relying on automated decision-making using machine learning. Neither the draft regulation on combating unlawful content (DSA) nor the new draft on harmonized rules for artificial intelligence create fundamental obstacles in this regard. ${ }^{15}$

However, one should bear in mind that such automated systems would be classified as highly risky under the draft Artificial Intelligence Act. This, in turn, could seriously impede the efforts of system creators to rapidly introduce such solutions on the EU market. Secondly, in light of the

14 Regulation (EU) 2016/679 of the European Parliament and of the Council of 27 April 2016 on the protection of natural persons with regard to the processing of personal data and on the free movement of such data, and repealing Directive 95/46/EC [2016] OJ L119/1-88 (General Data Protection Regulation).

15 Proposal for a REGULATION OF THE EUROPEAN PARLIAMENT AND OF THE COUNCIL LAYING DOWN HARMONISED RULES ON ARTIFICIAL INTELLIGENCE (ARTIFICIAL INTELLIGENCE ACT) AND AMENDING CERTAIN UNION LEGISLATIVE ACTS of 21 April 2021 r. COM(2021) 206 final 
GDPR the data subject shall have the right not to be subject to a decision based solely on automated processing, including profiling, which produces legal effects concerning him or her or similarly significantly affects him or her (art. 22 par. 1). Therefore, AI-based approaches should rather be used as a complementary element to the traditional IT systems operated by human experts.

A very important element of the proposed ODR architecture is the definition of how to ensure financial stability of such platforms. After all, they have to support their operations as well as to ensure the quality of their judgments and the smooth functioning for a longer period of time. The DSA provides for the possibility of establishing public ODR by Member States but the functioning of private entities is far less clear.

The DSA regulation provides for the possibility of charging fees for dispute resolution. These these fees should not be excessive and should not exceed the cost of providing the service. This, in turn, may turn out to be a challenge in building sustainable online dispute resolution systems, as it is simply hard to tell at this point, what is the cost of providing such service. There are too few examples to draw conclusions from.

The draft DSA also made some important stipulations changing the burden of costs associated with loosing a case. If the dispute is resolved in favour of the online trader's counterparty, the counterparty will be obliged to reimburse the entire cost of dispute resolution incurred by the trader, whereas if the professional entity wins, the counterparty will not be obliged to reimburse the expenses incurred by the online trader (Article 18(3) of the draft DSA).

\section{Features of the ODR platform}

The proposed model of the European Commission in the DSA is quite generic and will therefore require a lot more planning and engineering effort to develop a comprehensive set of features for such a platform to function well. Even the most basic features of the proposed out-of-court ODR are missing. Therefore, it is worthwhile to revisit the older, already mentioned Regulation 524/2013 to see what requirements the European legislator has envisaged for ODR platforms for consumer disputes to see if they could be adapted for settling disputes related to unlawful content. It is worth pointing out that the aforementioned Regulation often uses a more generic term ADR (Alternative Dispute Resolution) rather than a more restrictive, purely Internet-based ODR (Online Dispute resolution). 
According to Article 5(4) of the Regulation 524/2013 on ODR in consumer disputes, the ODR platform should offer the following features:

(a) providing an electronic complaint form that can be completed by the complainant. This is a self-evident requirement; moreover, the complaint form should be accessible to persons with various disabilities, including visual impairments;

(b) informing the party against whom the complaint is made about filing of the ODR complaint. This is also an integral part of the due process, which should be the cornerstone of the information flow envisaged by the unlawful content dispute resolution platform;

(c) identifying the relevant adjudicator (i.e. arbitrator, mediator or conciliator). The Regulation 524/2013 uses a more generic term "ADR entity" 16 instead and mandates forwarding the complaint to the ADR entity that the parties have agreed to use. This requirement can be seen as an extension of the due process principle by requiring that the case be referred to another entity as indicated in the agreement concluded between the complainant and the online trader;

(d) the provision, free of charge, of an electronic case handling tool that will enable the parties and the adjudicator (ADR entity) to conduct their online dispute resolution proceedings through the ODR platform. In fact, the above requirement is so broad that it will need to be spelled out in detail in terms of the detailed functionalities of the platform, including how the "hearing rooms" will be visualized, the scope of information provided to the parties, the adjudicator and the administration of the platform, etc. On the other hand, with regard to payments, draft DSA regulation provides for the possibility of charging fees, which is one of the main differences with respect to the consumer dispute resolution model;

(e) provide the parties and the adjudicator (ADR entity) with a translation of the information that is necessary for the resolution of the dispute and that is exchanged through the ODR platform. This is an interesting requirement, the implementation of which should also be

16 'ADR entity' means any entity, however named or referred to, which is established on a durable basis and offers the resolution of a dispute through an ADR procedure and that is listed in accordance with Article 20(2) of the Directive 2013/11/EU of the European Parliament and of the Council of 21 May 2013 on alternative dispute resolution for consumer disputes and amending Regulation (EC) No 2006/2004 and Directive 2009/22/EC (Directive on consumer ADR) [2013] OJ L165/ 63-79 (Directive on consumer ADR). 
recommended to all ODR platforms. It may give raise to the possibility of additional fees being charged, of which the complainant would have to be informed of before initiating the dispute. Alternatively, such translation service could also be provided by a machine learning solution;

(f) making available mechanisms, such as an electronic form, by means of which adjudicator (ADR entity) can share with other participants the details of the complaint at hand, namely: (i), the date of receipt of the complaint file; (ii), the subject matter of the dispute; (iii), the date on which the procedure was concluded; (iv), the outcome of the procedure. The Regulation 524/2013 presupposes handling of such administrative duties by a relevant entity rather than an administrative unit within an ODR platform. This, however, can be adapted to the needs of centralised, purely-online service providers.

(g) the provision of a feedback system allowing the parties to express their views on the functioning of the ODR platform and on the adjudicator (ADR entity) that handled their dispute. This is also an interesting requirement concerning on the level of service offered by the ODR platform, which was not imposed with respect to e.g. traders dealing with consumers. It would be interesting to see what kind of information can be gathered and distributed via such feedback forms. Especially, to what extent critical remarks concerning verdicts and/or adjudicators should affect the functioning of the ODR system;

(h) making publicly available statistical data on the outcome of disputes and general information on how to resolve disputes out of court, an online guide on how to lodge a complaint and contact information.

The above requirements provided by the 2013 Regulation are quite vague, especially in critical areas, such as"case handling tool" or mechanisms for sharing data with other participants. Nevertheless, it is necessary to foresee functional solutions in sufficient detail, such as issues related to the flow of necessary information in the dispute resolution system ranging from the registration of the case through its transfer to the adjudicators, the conduct of voting, the registration of the process to the announcement of the award and its transmission to the participants. In addition, platforms should be prepared to cover the details in the general terms and conditions of an ODR platform. 
Procedural requirements

The features or functional requirements envisaged in Regulation 524/2013 are a good starting point for further elaboration of the characteristics of the unlawful content dispute resolution model. In this context, it is worth a second block of functional solutions provided in Articles 8 and 9 of the Regulation on consumer ODR, which can be described as procedural or workflow architecture requirements.

\section{1) Complaint form}

In order to submit a complaint to the ODR platform, the complainant shall fill in an electronic complaint form and the European Commission has been obliged to define an electronic complaint form by means of implementing acts. The complaint form should be user-friendly and easily accessible on the ODR platform. This means that the form must be accessible within the meaning of WCAG 2.1 principles, in particular the fields of the form must be constructed in such a way that .e.g. a visually impaired person can enter and submit the information stored therein to the ODR system.

The information to be submitted by the complaining party must be sufficient to determine the competent entity (an adjudicator) that will deal with the complaint (in the context of consumer disputes, this is the designation of the relevant ADR entity that will actually deal with the dispute using ODR platform). ${ }^{17}$ In the context of illegal content, this may entail an elaboration of the algorithm for selecting relevant adjudicators specialising in a given area of illegal content.

The complainant should be able to attach documents in support of their complaint. This means building an infrastructure to upload and store files, including both text files, photos and scans of paper documentation. One should consider expanding the document retrieval functionality to include

17 In the Consumer Disputes Regulation, ADR entities handling complaints must comply with the relevant requirements. Article 8 of the Regulation provides that in order to take into account the criteria on the basis of which ADR entities listed in accordance with Article 20(2) of Directive 2013/11/EU and handling disputes covered by this Regulation define their respective scopes of competence, the Commission shall be empowered to adopt delegated acts in accordance with Article 17 of this Regulation adapting the information listed in the Annex to this Regulation. 
screenshots for evidentiary purposes along with the date of the screenshot and perhaps a digital signature.

\section{2) Collection and retention of personal data contained in the complaint}

Article $8(5)$ of the Regulation 524/2013 provides that the electronic complaint form and its attachments shall only be processed in respect of data that is accurate, relevant and not excessive in relation to the purposes for which it was collected. The above provision is not well structured taking into account the entirety of the personal data protection standards, and therefore its meaning should be decoded in the light of the general principles relating to the processing of personal data contained in the GDPR, i.e. in particular the principle of lawfulness, the principle of purpose limitation, the principle of data minimization, the principle of short period of data retention and the security of data processing, as well as the necessity to demonstrate the way in which the above principles are implemented.

Particularly noteworthy are the principle of prohibiting the processing of sensitive data and the principles of privacy by design and privacy by default. The first principle concerns the prohibition of the collection, storage and processing of data that leads to facilitating discrimination against people on the basis of skin color, gender, health status, sexual preference, political opinions, etc., unless the processing is permitted by one of the exceptions set out in Article 9(2) of the GDPR. On the other hand, the second group of principles concerns the consideration of all technical ways to minimize privacy risks by using mechanisms such as encryption, data minimization, and data anonymization (or pseudonymization) to increase the resilience of data sets to the effects of loss of access to data.

\section{3) Pre-dispute information}

The Regulation 524/2013 provides that a complaint submitted via the ODR platform shall be considered if all required fields of the complaint form are completed. If the complaint form is not filled in completely, the complainant shall be informed that the complaint cannot be further processed unless the missing information is provided (Article 9(2) of the Regulation).

In accordance with Article 9(3) of the Regulation, upon receipt of a fully completed complaint form, the ODR platform shall clearly and prompt- 
ly transmit to the party complained against, in any official language of the Union institutions chosen by that party. ${ }^{18}$

\section{4) Handling of the case by the ODR entity}

The ODR platform should automatically and immediately forward the complaint to the adjudicator appointed by the parties in accordance with their agreement. The ADR entity to which the complaint has been transmitted is obliged to inform immediately the parties whether it agrees to deal with the dispute or declines to do so (which it may do in accordance with Article 5(4) of Directive 2013/11/EU). The ADR entity that has agreed to deal with the dispute shall also inform the parties of its procedural rules and, where applicable, of the costs of the dispute resolution procedure in question.

In accordance with Article 8(9) of the Regulation 524/2013, where within 30 calendar days of the submission of the complaint form the parties have not reached an agreement with the ADR entity or the ADR entity refuses to deal with the dispute concerned, the complaint should not be processed further. The complainant shall be advised to contact the ODR adviser for general information on other means of redress.

18 The complaint should be sent together with the following (a) an indication that the parties must agree on an ADR entity in order for the complaint to be transmitted to it, and that in the event of disagreement between the parties or failure to identify an appropriate ADR entity, the complaint shall not be processed further;

(b), information on the ADR entity or entities that are competent to deal with the complaint, insofar as such entity or entities have been named in the electronic complaint form or have been identified by the ODR platform on the basis of the information provided in that form;

(c) if the party against whom the complaint is lodged is a trader, a request to determine within 10 calendar days

- whether the trader is obliged or has committed itself to use a specific ADR entity to resolve disputes with consumers, and

- if the trader is not obliged to use a specific ADR entity, whether he is willing to use one or more ADR entities referred to in point (b);

(d) where the party against whom a complaint has been lodged is a consumer and the trader is obliged to use a specific ADR entity, a request to agree within 10 calendar days to that ADR entity or, if the trader is not obliged to use a specific ADR entity, a request to select one or more ADR entities referred to in point (b);

(e) the name and contact details of the ODR contact point in the Member State of the complainant's habitual residence or place of establishment and a brief description of the functions referred to in Article 7(2)(a). 


\section{Recommendations concerning ODR systems}

The proposed model for online dispute resolution with respect to illegal content in the draft DSA has one major drawback. ODR as a service is available only to customers of larger Internet entities, rather than to all online entrepreneurs. Such approach may deprive the contractor of smaller and medium-sized enterprises of access to online out-of-court dispute resolution, such as online arbitration, mediation or conciliation.

It is proposed to offer access to out-of-court dispute settlement to a broader category of customers. The right to review a decision made by an online businesses should be accessible to a greater number of customers. One should keep in mind that out-of-court dispute resolution service should not be a burden for the small and medium-sized enterprise (SMEs) in the sense that it is provided by a third party and relieves them from strategic legal risks. On the other hand, this may entail some further deliberations on how to ensure proper financing of the ODR platforms. Consequently, Article 18 of the DSA draft should be placed earlier, i.e. in Section 1 of the DSA.

Financing of ODR systems should be given a second thought. A model envisaged in the draft DSA regulation relieves the users of online platforms from reimbursing the costs of the proceedings. Although the proposal seems appropriate with respect to large online platforms, it would be hard to accept for SMEs operating in cyberspace. This may be a reason why a right to out-of-court dispute settlement in case of illegal content was not extended to customers of smaller online businesses. But this is not a good solution, either. A clear model should be developed, which incentivizes providers of online services to support independent online dispute resolution centers to relieve them from a burden of self-deciding about the legality of blocking or removing questionable content.

The existing legal framework(s) do not presuppose arbitration, mediation or conciliation as methods of alternative dispute resolution in cyberspace. It is therefore up to the creator of such platform to assume one or all of the defining characteristics of online dispute resolution model. ODR systems developed on the basis of the draft DSA legislation to handle illegal content should take into account the EU legislation that established some early requirements for handling disputes online. In particular, the Regulation 524/2013 could be a good a starting point for the development of detailed requirements that ODR systems should fulfil in the area of tackling illegal content, such as privacy by design and privacy by default.

One important requirement for ODR system to be potentially borrowed from the Regulation 523/2013 should be a feedback system. A majority 
of modern information society services provide functionality for assessing sellers or service providers. Such feedback mechanism could also be a part and parcel of the ODR model as it would help to provide a better service in future. There are, however, challenges related to the impartiality of adjudicators that should be more thoroughly examined.

All web forms, including text boxes, text areas, radio buttons and other user interface components should be accessible by design. This entails the necessity to develop ODR systems with the Web Content Accessibility Guidelines in mind to make sure that people with various disabilities can access both content as well as user interface elements in a non-discriminatory manner. Content of ODR systems should be perceivable to all humans, operable not only by mouse but also by keyboard and similar input devices, understandable both to humans and assistive technologies and technically robust, including compatibility with older devices and technologies.

Privacy by design and privacy by default should be the guiding principles when constructing user forms and databases for storing user-defined content. On one hand side, ODR system should enable processing of not only harmful message(s) but also its context (e.g. not only a harmful comment but the whole thread in a discussion forum). On the other hand, the collection and processing of personal data should be minimised and kept for a set period of time. Other obligations resulting from the GDPR and the future ePrivacy regulation should be also taken into account. In any case, the EU lawgiver should give a second thought to exemptions for processing personal data in the context of online dispute resolution systems in order to ease its functioning.

The EU legal framework for ODR in consumer disputes assumes that the ODR platform does not need to provide dispute solving functionalities and can act as an integrator of verdicts issued by independent, national ADR entities. In other words, the online consumer dispute resolution model is not based on a philosophy of resolving problems through a dedicated online platform, but on referring the dispute to third-party entities (ADR entities) that may or may not take on the challenge of resolving the dispute. Such an architecture has its advantages, in particular if it is assumed from the outset that the system should operate in all EU countries simultaneously, and that the ODR platform should serve as the basic mechanism for routing and exchanging information. But the drawback is that legal requirements are vague.

A lot of technical issues would still need to be clarified in future legislation concerning ODR in order to build a full-fledged online dispute 
resolution system based on an IT centralized model for resolving legal issues in cyberspace, such as:

the content of forms for different categories of cases (including from the GDPR perspective), also for evidentiary purposes, the way disputes are resolved through the platform, how voting and decision-making will be documented, how "second instance" review of decisions will be carried out, and

how and to what extent information is communicated externally to dispute participants as well as to the public.

An important aspect of creating the architectural framework for such systems will be to take into account the recruitment of arbitrators, including the possibility of relying on so-called trusted third parties, e.g. NGOs fighting pathologies in cyberspace, or law firms specializing in these issues. An important issue from the perspective of resolving disputes in the area of freedom of speech on the Internet will also be the question of recognition of such awards by national courts, but this is an area where it is difficult to have any influence.

\section{Part II. Arbitration covenant. The concept}

In the Polish Code of Civil Procedure, Title II of Part V regulates the arbitration covenant. The provision of Art. 1161 section 1 of CCP defines this concept, indicating that submitting a dispute to an arbitration court requires an agreement between the parties in which the subject of the dispute or the legal relationship from which the dispute has arisen or may arise must be specified. In Polish literature it is indicated that the arbitration covenant in the Polish procedural law corresponds to the German Schiedsvetrag and combines the French clause compromissoir and compromis. However, this term is characteristic of Polish law only because international law uses the term arbitration agreement ${ }^{19}$. The term is thus used in the Polish Act on International Private Law of $2011^{20}$.

19 E.g., Art. II paragraph 1 of the New York Convention, which does not use the term "arbitration agreement" but specifies that each contracting state will recognize a written agreement which the parties agree to submit to arbitration. On the other hand, the term "arbitration agreement" is used by the UNCITRAL Model Act in Art. 7 in options I and II.

20 Act of 4 February 2011 - International Private Law, Journal of Laws of 2015, item 1792, where even chapter 8 was titled Arbitration Agreement. 
In arbitration proceedings, it is possible to resolve not only disputes that have already arisen between the parties, i.e., post litem natam, but also disputes that may arise in the future from a specific legal relationship. Hence, under Polish law, two types of arbitration agreement can be distinguished: a compromise ${ }^{21}$, i.e., an arbitration covenant in the strict sense of the word, and an arbitration clause ${ }^{22}$.

The essence and inseparable feature of an arbitration agreement in Polish law is its connection with a binding resolution of an arbitration court, and therefore an arbitration covenant is not an arbitration agreement, which does not provide for a judicial function for the arbitration court. This is due to the fact that the jurisdictional element is a feature of an arbitration covenant, i.e., submission of a dispute to an arbitration court $^{23}$. The essence of the arbitration covenant also results from the provision of Art. 1161 section 1 of CCP which indicates that submitting a dispute to an arbitration court must be included in the arbitration covenant itself. The settlement of a dispute is an arbitrary, imperative process based on coercion or authority and consisting in imposing the decision on the parties $^{24}$.

Therefore, the resolution of a dispute in arbitration is the authoritative imposition of a decision ending a dispute on the parties to the proceeding by a third party, i.e., an arbitrator or a panel of arbitrators. Therefore, the subject does not have the power to make imperative decisions. However, it should be noted that the purpose of arbitration and its adjudicative character do not invalidate its amicable nature, which means that arbitration belongs to one of the forms of ADR (Alternative Dispute Resolution). However, the Polish Act on ADR uses a different term, namely out-ofcourt resolution of consumer disputes ${ }^{25}$.

21 Michał Janowski, 'Zapis na sąd polubowny de lege lata i w świetle projektowanych zmian' in Józef Skoczylas (ed) Prace laureatów konkursu im. Prof. J. Jakubowskiego (PWN 2005) $33 \mathrm{ff}$.

22 M. Tomaszewska in Andrzej Szuamński (ed) System Prawa Handlowego. Arbitraż handlowy, vol. 8 (C. H. BECK 2015) $325 \mathrm{ff}$.

23 Grzegorz Żmij, 'Zapis na sąd polubowny' (2014) e-Przegląd Arbitrażowy special edition after the conference on Diagnosis of Arbitration. Functioning of the law on arbitration and directions of the postulated changes 95; also: judgment of the Supreme Court of 11 July 2001, V CKN 379/00, OSNC 2002, No 3, item 37; Robert Kulski 'Glosa do wyroku SN z dnia 17 listopada 2000 r., V CKN 1364/00' (2002) 11 PiP 103.

24 Arkuszewska (n 4) 231; Korybski (n 4) 32.

25 Arkuszewska (n 4) 232. 


\section{Legal nature of an arbitration agreement}

In order to determine the form in which an arbitration covenant may be concluded in Polish law, it is essential to initially determine what the legal nature of this clause is. The problem of the nature of the arbitration covenant arises from the very essence of arbitration. Arbitration is less formal than common courts in terms of the way a case is examined. As a result of this assumption, the Polish Procedural Act does not contain detailed solutions concerning the course of arbitration proceedings. The legal nature of the arbitration covenant is the reason for numerous disputes in the Polish doctrine of civil law, civil procedure law and private international law. And so, it is assumed that the arbitration covenant is the so-called procedural contract ${ }^{26}$; legal transaction, i.e., an action subject to the regime of substantive civil law ${ }^{27}$; an action of a material and procedural nature ${ }^{28}$ or a sui generis action ${ }^{29}$. Recently, other views have also emerged, namely that an arbitration covenant is a special type of a private-procedural agreement ${ }^{30}$, or a legal action taken to pursue claims (action to pursue rights) ${ }^{31}$.

26 Bogusław Sołtys, 'Forma umowy o arbitraż' in Maksymilian Pazdan, Wojciech Popiołek, Eewa Rott-Pietrzyk and Maciej Szpunar, Europeizacja prawa prywatnego, vol. 2, (Wolters Kluwer 2008) 408; Maciej Tomaszewski, 'Umowa o arbitraż. Podstawowe problemy prawne' (1994) 1 PUG 15; Tadeusz Ereciński and Karol Weitz, Sąd arbitrażowy(LexisNexis 2008) 85; Robert Kulski, Umowy procesowe w postepowaniu cywilnym (Wolters Kluwer 2006) 167.

27 Elwira Marszałkowska-Krzes and Łukasz Błaszczak, 'Zapis na sąd polubowny. A czynności materialne (wybrane zagadnienia)' (2007) 9 Rejent 12 ff.; Łukasz Błaszczak, Wyrok sadu polubownego w postepowaniu cywilnym (Wolters Kluwer 2010) 104; Łukasz Błaszczak, 'Charakter prawny umowy o mediacje' (2008) 1 ADR. Arbitraż i Mediacja 1-27.

28 Roman Kuratowski, Sądownictwo polubowne. Studium teoretyczno-praktyczne z uwzględnieniem prawodawstwa obowiąującego w trzech dzielnicach Rzeczypospolitej $i$ polskiego kodeksu postepowania cywilnego z roku 1930 (Księgarnia F.Holesicka 1932) 23-35.

29 Marian A. Myrcha, Sady polubowne $w$ prawie kanonicznym. Studium prawoporównawcze (KUL 1948) 186 ff.; Maksymilian Pazdan, Prawo właściwe dla oceny zapisu na sąd polubowny (2003) 10 Rejent 176; arbitration agreements.

30 AndrzejW. Wiśniewski, Międzynarodowy arbitraż handlowy w Polsce. Status prawny arbitrażu $i$ arbitrów (Wolters Kluwer 2011)77 ff.

31 Aleksandra Budnik-Rogala, Charakter prawny zapisu na sąd polubowny $w$ postepowaniu cywilnym (Uniwersytet Wrocławski 2015) $107 \mathrm{ff}$. The Author considers that an arbitration agreement does not fulfil the requirements specific to procedural actions. It cannot be assumed that it is a substantive law agreement or a substantive law action. The provisions of the Code of Civil Procedure, i.e., the proce- 
It has been assumed in the jurisprudence of the Supreme Court that an arbitration covenant combines the features of a substantive and procedural agreement. Although in the decision of 7 November 2013 the Supreme Court stated that the arbitration covenant concerns the broadly defined jurisdiction of the court to examine the case, and its main effect is the exclusion of the jurisdiction of the state court. Therefore, this goal falls within the broadly understood functionality of the definition of a procedural action. An arbitration covenant has a procedural effect by excluding the state judiciary from examining the case covered by the covenant ${ }^{32}$. Thus, regardless of the adopted concept of assessing the legal nature of an arbitration covenant, it is necessary to determine which provisions will be applicable to assess the validity of an arbitration covenant, therefore, in Polish doctrine it is assumed that the provisions on the arbitration covenant contained in the Code of Civil Procedure should be applied first, and in unregulated matters, the provisions of the Civil Code on legal transactions should be considered ${ }^{33}$. A similar view was also expressed by the Supreme Court in the resolution of 8 March 2002, where it stated that when adopting the substantive nature of the arbitration covenant, the provisions of the Civil Code should undoubtedly be applied to it, nevertheless, also in a situation when the arbitration covenant is assigned the form of a procedural agreement, in matters not regulated in the Code of Civil Procedure, the provisions of the Civil Code on legal transactions should be applied ${ }^{34}$. Of course, when an arbitration covenant is included in a commercial contract, as an arbitration clause, it is necessary to assess, for example, the legal capacity of the parties to perform a substantive action in accordance with the provisions of the Civil Code, and the assessment of the capacity to establish the covenant - court capacity, procedural capacity ${ }^{35}$.

dural act, apply to an arbitration covenant, but in matters not regulated by CCP, the provisions of the Civil Code in the scope of legal actions can be applied.

32 Cf. decision of the Supreme Court of 22 February 2007, IV CSK 200/06, OSNC 2008, No 2, item 25; decision of the Supreme Court of 7 November 2013, V CSK 545/12, Lex No 1422127.

33 Zbigniew Radwański, 'Glosa do postanowienia SN z 13.06.1975 r., II CZ 91/75' (1977) 5 OSPiKA 204; Andrzej Jakubecki, 'Poddanie się egzekucji w akcie notarialnym' (1998) 12 Rejent 67.

34 Resolution of the Supreme Court of 8 March 2002, III CZP 8/02, OSNC 2002, No 11 , item 133.

35 Jakubecki (n 33) 67. 
Form of arbitration agreement

\section{Written form}

The above considerations will now allow us to discuss the form of an arbitration covenant according to the Code of Civil Procedure in Poland. Therefore, determining in what form the arbitration clause should be concluded is of fundamental importance for the assessment of its validity. The provision of Art. 1162 section 1 of CCP stipulates that the arbitration covenant should be concluded in writing, i.e., pursuant to Art. 78 section 1 et seq. of CC.

The jurisprudence ${ }^{36}$ assumes that the method of concluding an arbitration covenant, specified in Art. $1162 \$ 2$ sentence 1 of CCP is an alternative method to the principles set out in Art. $1162 \$ 1$ of CCP. There was even an opinion that the provision of Art. $1162 \$ 2$ of CCP is a lex specialis in relation to Art. 78 of CC because it aims at the liberalization of form ${ }^{37}$.

In a situation where the dispute arises from an agreement which requires a special form to be valid (e.g., the form of a notarial deed), the regular written form is sufficient for the arbitration covenant to be valid ${ }^{38}$.

It is worth reminding that the written form of $a b$ arbitration agreement has also been provided for in other legal systems. And so, section 1031 paragraph 1 of ZPO requires a written form when drawing up the arbitration agreement, although unlike in Art. $1162 \rrbracket 1$ of the Polish CCP. According to its wording, the arbitration covenant must be concluded either in a document signed by the parties or in letters, faxes, telegrams, or other means of distance communication exchanged by them, which secure the proof of concluding the agreement. Therefore, this provision contains two alternatives. The first one corresponds to the content of Art. $1162 \$ 1$ of CCP. The

36 Judgment of the Court of Appeal in Warsaw of 27 October 2010, I ACa 498/10, LEX No 1643011.

37 Beata Gessel-Kalinowska vel Kalisz in Beata Gessel-Kalinowska (ed) Postepowanie przed sadem sądem polubownym. Komentarz do Regulaminu Sądu Arbitrażowego przy Konfederacji Lewiatan (Wolters Kluwer 2015) 61.

38 Judgment of the Supreme Court of 23 April 1936, II C 110/36, PPC 1936/19, 605; Sławomir Dalka, Sadownictwo Polubowne w PRL(Wydawnictwo Prawnicze 1987) 58; Robert Kulski, Umowy procesowe w postępowaniu cywilnym, (Wolters Kluwer 2006) 213; Łukasz Błaszczak and Małgorzata Ludwik, Sadownictwo. Polubowne (arbitraż) (C. H. BECK 2007) 114; Aleksandra Budniak, 'Forma zapisu na sad polubowny w świetle polskiego i niemieckiego postepowania cywilnego zagadnienia prawnoporównawcze’ (2009) 4 ADR. Arbitraż i Mediacja 19. 
second one contains a regulation similar to Art. $1162 \$ 2$ of CCP. Due to the significant similarity to the provisions of substantive law on the form of a legal transaction, the norm contained in $\$ 1031$ section 1 of ZPO is often referred to as "the modified written form of $\$ 126$ of BGB" ("Modifizierte Schriftform des $\left.₫ 126 \mathrm{BGB}^{\prime \prime}\right)^{39}$. The signatures of the parties to the arbitration covenant do not have to be placed on the same document. If the arbitration agreement was drawn up in the form of several identical documents, it is enough for each party to sign a copy intended for the other party $(\mathbb{S} 126 \text { paragraph } 2 \text { of } \mathrm{BGB})^{40}$.

There is a divergence of views in German literature - whether a signature has to be handwritten or not ${ }^{41}$. The legal form provided for in $\$ 1031$ serves, like all formal requirements, legal certainty. The German literature indicates that the form of an arbitration agreement covers two main areas. The legislator separates an arbitration agreement involving a consumer from the one used in professional trade. In the case of an agreement involving a consumer, stricter formal requirements are intended, in particular, to protect the consumer within the meaning of the so-called warning function, while in business transactions the normal written form is more flexible (paragraphs 1-4) ${ }^{42}$. In cases without the participation of the consumer, the legislator did not recognize that there are special protective mechanisms to protect the parties from themselves. Arbitration, which plays a large role in economic life, would be very limited if such formalism were practiced $^{43}$.

Similarly, in $₫ 583$ of ZPO, the arbitration covenant must be contained either in a document signed by the parties, or in letters, faxes, e-mails, or

39 Cf. Karl H. Schwab, Gerhard Walter and Adolf Baumbach, Schiedsgerichtsbarkeit Kommentar (C. H. BECK 2005) 37 ff.; Wilhelm Harmann, 'Zum Schriftformerfordernis fur Schiedsvereinbarungen' in Stefan Grundmann and others, Festschrift fur Klaus J. Hopt zum 70. Geburtstag am 24. August 2010: Unternehmen, Markt und Verantwortung (De Gruyter 2010) 2777-2778; Rolf A. Schutze in Rolf A. Schutze and Bernhard Wieczorek, Zwilprozessordnung und Nebengesetze. Grofikommentar (De Gruyter 2014) 383; Budniak (38) 19.

40 Schwab, Walter and Baumbach (n 39) 38.

41 Cf. Schutze and Wieczorek (n 39) 384, indicate that, according to $\$ 126$ of BGB, the signature must be handwritten or certified by a notary. A mechanical reproduction in writing of the signature specimen, e.g., by a matrix or facsimile, is not a handwritten signature; differently Adolf Baumbach, Wolfgang Lauterbach, Jan Albers and Peter Hartmann, Zivilprozessordnung (C. H. BECK 2007) 2600.

42 Hanns Priitting and Markus Gehrlein, Zivilprozessordnung. Kommentar (Luchterhand Verlag 2016) 2393 et seq.; cfSchwab Walter and Baumbach, (n 39) 43-44.

43 Schiitze and Wieczorek (n 39) 386. 
other forms of transmission of messages exchanged by them, which constitute evidence of the conclusion of the covenant.

In French law, the issue of the form of an arbitration agreement is included in Art. 1443 of the French Code of Civil Procedure. According to this provision, the arbitration agreement must be in a written form in order to be valid. This form is observed, if it follows from written correspondence, in a document to which it relates, contained in the main agreement ${ }^{44}$. Similarly, the Italian Code of Civil Procedure in Art. 807 assumes that the arbitration agreement should be, otherwise null and void, concluded in writing and specify the subject of the dispute. The written form is also considered to be observed when the will of the parties is expressed by means of a telegraph, teletype, fax, or electronic communication, in compliance with the standards, including the regulations, regarding the sending and receiving of documents transmitted remotely ${ }^{45}$.

On the other hand, in Spanish law, the arbitration laws also stipulate that the arbitration agreement should be concluded in writing, in a document signed by the parties, or in the exchange of letters, telegrams, telexes, faxes or other means of distance communication that make it possible to record the content of the agreement (Art. 9 paragraph 3$)^{46}$.

44 Cf. JeanL. Delvolve, Jean Rouche and Gerald H. Pointon, French Arbitration Law and Practice (Wolters Kluwer 2003) 297.

45 Art. 807 Italian of CCP is a kind of a fiction of keeping the written form in the circumstances specified in this provision - Michał Bieniak, 'Polska regulacja postępowania arbitrażowego na tle przepisów włoskiego Kodeksu postępowania cywilnego' (2009) 3ADR. Arbitraż i Mediacja 9.

46 Gorgonio M. Atienza, Comentarios a la Ley de Arbitraje (Editorial v Lex 2011) 104-118. 


\section{Electronic form of an arbitration agreement}

Under Polish law, an arbitration agreement may be drawn up in an electronic form with the use of a qualified electronic signature. Article $781 \rrbracket 1$ of CC states that in order to maintain the electronic form of a legal transaction, it is sufficient to submit a declaration of will in an electronic form and affix a qualified electronic signature to it ${ }^{47}$. After the entry into force of the Regulation of the European Parliament and of the Council on electronic identification and trust services for electronic transactions in the internal market ${ }^{48}$ on 1 July 2016 (Art. 52 paragraph 2 of the Regulation) and the Act of 5 September 2016 on trust services and electronic identificati$\mathrm{on}^{49}$ for the application of this Regulation, the terminology of this signature was changed in order to align the term used in it with the nomenclature adopted in the eIDAS Regulation. As a reminder, it can be noted that pursuant to Art. 3 point 12 of the eIDAS Regulation, "qualified electronic signature" means an advanced electronic signature that is created by a qualified electronic signature creation device, and which is based on a qualified certificate for electronic signatures. A qualified electronic signature creation device can only rely on the configured software, not on the device and software. Qualified electronic signature creation devices as well as qualified electronic signature certificates ${ }^{50}$ must meet the requirements speci-

47 Until 2016, this signature was called "secure electronic signature verified with a valid qualified certificate".

48 Regulation (EU) No 910/2014 of the European Parliament and of the Council on electronic identification and trust services for electronic transactions in the internal market and repealing Directive 1999/93/EC [2014] OJ L257/73 (eIDAS). The eIDAS regulation introduces a uniform terminology in all Member States, increases the requirements for liability in terms of security, expands the catalogue of trust services, and provides for clear rules for supervision over trust service providers. It is interdisciplinary, cross-sectoral, and pan-European, based on two key elements: security and trust. At the same time, the eIDAS regulation is open to innovative solutions and services such as mobile signatures - cf. Magdalena Marucha-Jaworska, Rozporządzenie eIDAS. Zagadnienia prawne i techniczne (Wolters Kluwer 2017) 15; Maria Siemaszkiewicz, 'Rozporządzenie eIDAS - nowe ramy prawne w zakresie identyfikacji elektronicznej i usług zaufania w Unii Europejskiej' (2016) CYII AUWr PPiA 212.

49 Journal of Laws of 2019, item 162.

50 A qualified certificate is the basic tool for verifying the identity of the person signing an electronic document. It is the equivalent of an online identity card, but it is issued by a qualified trusted entity, however, it must be recognized by all EU entities, the administration or the broadly understood system of justice. In the event of its revocation, this fact is registered in the database of a qualified trust 
fied in Annexes II and I, respectively, to the eIDAS Regulation. A qualified electronic signature may be issued only by a trusted entity within the meaning of eIDAS, and in Poland it also must meet the requirements of the Act on trust services and needs to be entered on the list of trusted entities.

The court should not analyse technological solutions, but limit itself to formal issues, as the eIDAS Regulation introduced a rule that a qualified electronic signature, which is on the list of notified e-signatures, complies with the Regulation and must be recognized in legal transactions. Examination, whether a given qualified e-signature meets the requirements of an EU legal act is carried out at the stage of entering it on the certification list kept by any of the Member States. If the e-signature is already included in such a list, it is presumed to be compliant with the eIDAS Regulation. The court could therefore limit itself to checking the register of qualified trust services kept by the National Certification Centre.

\section{Document-like form}

In Polish law, the concept of a document has been defined very broadly in Art. 773 of CC, thus, a division is made into evidence from documents containing text, enabling the identification of issuers and other documents ${ }^{51}$. The concept of a document is sometimes used on a par with other terms, such as "letter", "written form of legal transactions", "receipt" or "notarial deed", so the main purpose of this definition is to organize the terminology ${ }^{52}$. The constitutive feature of a document is its intellectual content - information, content, which includes various statements, including a declaration of will. The content of the document should be recorded in an appropriate way that allows it to be recreated, so there is no need to sign the document.

service provider and published online. In practice, everyone from that moment on, in the case of verification of a qualified certificate, when a signature is made after its revocation, sees its invalidity in the signed document - more: Krzysztof Kamiński in Dariusz Szostek (ed), Bezpieczeństwo danych i IT w kancelarii prawnej radcowskiej/adwokackiej/notarialnej/komorniczej. Czyli jak bezpiecznie przechowywać dane w kancelarii prawnej (C. H. BECK 2018) 411-412.

51 Jacek Gołaczyński, 'Wpływ rozporządzenia eIDAS na polskie prawo prywatne. Wybrane zagadnienia' in Kinga Flaga-Gieruszyńska, Jacek Gołaczyński and Dariusz Szostek (eds) Media elektroniczne. Wspótczesne problemy prawne (C. H. BECK 2016) 7.

52 Justification for the draft act on trust services and electrical identification, 8th term of office, Sejm paper No 713, p. 3. 
Hence, it is ultimately considered that the signature is not a necessary element of a document ${ }^{53}$. After all, the content of the document may be disclosed in any way - e.g., by graphic symbols, image, or sound, and remains technologically neutral in accordance with the adopted European and international rules ${ }^{54}$. The content of the document can be recorded on any medium - it can be a file or paper, by any means, such as a computer or a mobile phone. The evidentiary function of a document limits technological neutrality - the method of recording information should enable its preservation and reconstruction. The information should therefore be properly recorded on the medium so that it can be reproduced. Thus, a document consists of two elements in total - information that can be reproduced and the medium on which its content has been recorded ${ }^{55}$.

In Polish law, the electronic form pursuant to Art. 78 (1) section 1 of $\mathrm{CC}$ is not a qualified form for the written form, however, it may replace the document-like form of a legal transaction, and it will not replace qualified written forms ${ }^{56}$. Consequently, drafting an arbitration covenant in an electronic form will be equivalent, in terms of legal consequences, to drafting a covenant in writing. It is emphasized in the literature that it is equivalent to the form, specifically to the written form ${ }^{57}$, which means that the reciprocal substitutability would refer to the reservation of the form in the act, although not necessarily in a pactum de forma ${ }^{5859}$.

For example, in German law there is also an electronic form of an arbitration covenant. Pursuant to $\$ 126$ of $\mathrm{BGB}$, it is used to interpret the provisions governing the form of an arbitration covenant. However, at the same time $\mathbb{} 126$ paragraph 3 of BGB indicates that, unless the Act provides otherwise, a written form may be replaced by an electronic form, thus there are no obstacles to use an electronic form in relation to an arbitration agreement.

53 Magdalena Marucha-Jaworska, Rozporządzenie eIDAS zagadnienia prawne $i$ techniczne (Wolters Kluwer 2017) 180.

54 See more: Magdalena Marucha-Jaworska, Podpisy elektroniczne, biometria, identyfikacja elektroniczna (Wolters Kluwer 2015) $282 \mathrm{ff}$.

55 Marucha-Jaworska ( $\mathrm{n} \mathrm{46)}$ 181; for more on the concept of a document, see the considerations on the document-like form of the arbitration covenant.

56 Grzegorz Stojek, 'Art. 78' in Mariusz Fras (ed) Kodeks cywilny. Komentarz. Tom I. Część Ogólna (Wolters Kluwer 2017).

57 Radosław Strugała 'Art. 78' in Edward Gniewek and Piotr Machnikowski (eds) Kodeks cywilny. Komentarz (C. H. BECK 2017)section 1.

58 Mateusz Grochowski, Skutki braku zachowania formy szczególnej oświadczenia woli (C. H. Beck 2017) 21.

59 Kamiński (n 50) 415. 
It should be remembered that when the written form reserved by the act is replaced by the electronic form, the issuer must attach his or her name to it and the document must be signed with a qualified electronic signature in accordance with the Act on electronic signatures. In a case of an agreement, the parties must submit an electronic signature on a superposable document issued in the above-mentioned manner $(\$ 126 \mathrm{a} \text { of } \mathrm{BGB})^{60}$.

Before the entry into force of the Act of 10 July $2015^{61}$, which introduced two new forms into the legal system - electronic and document-like there were two terms present in the literature ${ }^{62}$ : "qualified electronic form" in legal transactions, which required the use of a secure electronic signature; and "regular" electronic form of legal transactions, which did not require such a signature ${ }^{63}$. Thus, it was assumed that an arbitration covenant could be concluded in "a special form", which is a qualified electronic form ${ }^{64}$, as well as in "regular" electronic form (Art. $1162 \$ 2$ first sentence of CCP $)^{65}$.

However, currently, i.e., based on the Civil Code in the wording established by the Act of 2015 , it is reasonable to assume that the previously indicated "regular" electronic form may now be regarded as a document-li-

60 Cf. also $\$ 1031$ paragraph 5 of ZPO.

61 The Act of 10 July 2015 amending the Act - Civil Code, the Act - Code of Civil Procedure and some other acts (Journal of Laws, item 1311, as amended).

62 Jacek Gołaczyński, 'Wykorzystanie środków komunikacji elektronicznej w arbitrażu. W prawie polskim' in Andrzej Janik (ed) Studia i rozprawy, ksiega pamiątkowa dedykowana profesorowi Andrzejowi Całusowi (Szkoła Główna Handlowa 2009) 674; Dariusz Szostek and Marek Świerczyński, 'Arbitraż elektroniczny' ( 2009) 16 MoP 479; Berenika Kaczmarek-Templin, 'Kilka uwag o elektronicznej postaci umowy o arbitraż w kontekście przepisów regulujących formę zapisu na sąd polubowny' (2010) 3 ADR. Arbitraż i Mediacja 23; Ereciński, Weitz, (n 24) 127; Karol Weitz 'Art. 1162' in Tadeusz Ereciński (ed) Kodeks postępowania cywilnego. Komentarz. Tom 3 (Wolters Kluwer 2017), Art. 1162; Justyna Balcarczyk, 'Zagadnienie formy umowy o arbitraż w świetle art. II (2) Konwencji nowojorskiej o uznawaniu i wykonywaniu zagranicznych orzeczeń arbitrażowych oraz w świetle regulacji wewnętrznych'(2008) 4 ADR. Arbitraż i Mediacja 4.

63 Cf. Zbigniew Radwański, 'Elektroniczna forma czynności prawnej' (2001) 22 MoP 1107 et seq.; Ewa Wyrozumska, 'Elektroniczne oświadczenie woli w ustawie o podpisie elektronicznym i po nowelizacji kodeksu cywilnego' (2003) 8 PPH 45; WojciechJ. Kocot, Elektroniczna forma oświadczeń woli (2001)3 PPH 1 ff.; Bogusław Sołtys, 'Zawarcie umowy o arbitraż w formie elektronicznej' in Jacek Gołaczyński, Prawo umów elektronicznych (Wolters Kluwer 2006) 126-127; Sołtys (n 26) 408.

64 Cf. Kaczmarek-Templin (n 62) 23.

65 Szostek and Świerczyński (n 62) 479; Ereciński and Weitz (n 24) 127; Weitz (n 62). 
ke form ${ }^{66}$. A similar position can be adopted with regard to an arbitration covenant in the case of a covenant included in letters exchanged between the parties or statements made by means of distance communication that make it possible to record their content, i.e., it can be assumed that it is classified as a special form - document-like form of the arbitration covenant.

Therefore, Art. 772 of CC, concerning submitting a declaration of will in the form of a document, Art. 773 of CC, defining the term "document" and Art. $1162 \$ 2$ first sentence of CC should be assessed collectively.

The provision of Art. 772 of CC stipulates that in order to maintain the document-like form, it is sufficient to submit a declaration of will in a manner enabling the identification of the person submitting the declaration in one of the forms of the document defined in Art. 773 of CC. If it is possible to identify the author of the declaration of will, it is not possible to consider that it was submitted in document-like form. However, it is enough that the addressee may be able to identify the person making the declaration, as the legislator has not determined the necessity of identifying the person making the declaration by persons other than the addressee $^{67}$.

The need to identify the person submitting the declaration is not explicitly provided for in Art. $1162 \$ 2$ first sentence of CCP, which, however, clearly indicates that "the covenant was included in the letters or statements exchanged between the parties"68, therefore it specifies that the co-

66 Cf. Dariusz Szostek, 'Nowelizacja formy czynności prawnej wprawie cywilnym' (2017) 2 PME 47 - The document-like form is something between the written form and equivalent electronic form, and the fleeting, unregistered oral utterance. It leaves some kind of trace, evidence (although weak, but still much stronger than a fleeting oral statement), such as: e-mail message, SMS, internet portal, electronic banking.

67 Dariusz Szostek in Jacek Gołaczyński and Dariusz Szostek (eds) Informatyzacja postepowania cywilnego(C. H. Beck 2016) 65; Piotr Konik and Maciej Pannert, 'Materialnoprawne i procesowe aspekty formy dokumentowej i dokumentu' (2017/2018) 2Kwartalnik EP 38.

68 Cf. Art. 65' of CC. Conclusion of an arbitration agreement, pursuant to Art. 1162 $\$ 2$ first sentence of CCP requires the exchange of declarations by two parties made by means of electronic means of distance communication, however, such an agreement is concluded in the form of an offer, negotiation or using agreement templates made available in electronic form. The condition for the successful submission of an offer in electronic form is immediate confirmation of its receipt (Art. 66' $\$ 1$ of CC). However, the confirmation of receipt of the offer expressed in electronic form, as well as the acceptance of the offer may be made by any behaviour sufficiently revealing the fact of receiving the offer and its acceptance, so it 
venant is to be drawn up between the parties to the dispute, and this makes it necessary to identify these subjects - to determine whether the parties have entered into an arbitration agreement ${ }^{69}$. Hence, as a result of the liberalization of the form of legal transactions, pursuant to Art. 772 of CC and Art. $1162 \$ 2$ first sentence of CCP, the legislator does not provide for signatures by given entities when submitting declarations.

The provision of Art. $1162 \rrbracket 2$ first sentence of CCP uses the term "means of distance communication", but at the same time does not define this concept ${ }^{70}$. However, such a definition is contained in Art. 4 point 34 of Directive (EU) 2015/2366 of the European Parliament and of the Council of 25 November 2015 on payment services in the internal market ${ }^{71}$, according to which "means of distance communication" means a method which, without the simultaneous physical presence of the payment service provider and the payment service user, may be used for the conclusion of a payment services contract. Thus, it can be assumed that it will be any type of means that only allows communication between the parties without the simultaneous physical presence of the parties in the same place or even time. Moreover, the Act of 18 July 2002 on the provision of electronic services in Art. 2 point 5 defines the term "means of electronic communication", which are technical solutions, including ICT devices and software tools cooperating with them, enabling individual communication at a distance using data transmission between ICT systems, in particular electronic mail.

Similarly, Art. 4 paragraph 1 point (g) of the ODR Regulation defines the term "electronic means", which means electronic equipment for the processing (including digital compression) and storage of data which is entirely transmitted, conveyed, and received by wire, by radio, by optical means or by other electromagnetic means.

does not have to be expressed in the same form as the offer - Soltys, ( $\mathrm{n}$ 26) 413-414.

69 Cf. decision of the Supreme Court of 22 February 2007, IV CSK 200/06, OSNC 2008/2, item 25, which assumed that the conclusion of an arbitration covenant pursuant to Art. $1162 \$ 2$ first sentence of CCP must identify the sender. In contrast, Sołtys (n 26) 412, believes that in order to record the fact and content of an action, it is not always necessary to establish the identity of the person performing the action, but it is enough to confirm the authenticity of the action itself.

70 Journal of Laws of 2012, item 1225.

71 Directive (EU) 2015/2366 of the European Parliament and of the Council of 25 November 2015 on payment services in the internal market, amending Directives 2002/65/EC, 2009/110/EC and 2013/36/EU and Regulation (EU) No 1093/2010, and repealing Directive 2007/64/EC (OJ L337/35, as amended). 
Still, the most traditional and common means of distance communication are mobile phones (e.g., recording a covenant through a short text message, the so-called SMS, or recording a conversation) and electronic mail (e-mail).

In the Polish doctrine, there is a view that, for example, an audio or videophonic recording forwarded to the other party via the Internet or (recorded on a CD) by post does not meet the requirements of Art. $1162 \rrbracket 2$ of CCP.

In this case, we are dealing with the recording of the party's statement, but the statement is made orally. Therefore, just like a videophonic recording of the oral statements of the parties submitted simultaneously cannot be considered as maintaining a written form of an arbitration covenant (Art. $1162 \rrbracket 1$ of CCP), the parties providing each other with an audio or videophonic record of their statements should not be considered as maintaining the form specified in Art. $1162 \$ 2$ of CCP. It seems that the Author's view is justified when it comes to the exchange of information carriers with audio or videophonic recording, but the inability to pass an audio or videophonic recording to the other party via the Internet seems to narrow the scope of the concept of "means of distance communication" only to the possibility of recording them in writing, which may be questionable. The indicated "means" include any type of communication, including oral, written or even through a video only.

\section{Recommendations concerning arbitration agreement}

1. The arbitration agreement should be treated as a mixed, substantive and procedural agreement. Its purpose is to resolve a dispute arising from an obligation relationship by an arbitration court by selecting an arbitration court. It is also necessary to assume that the purpose of the arbitration agreement is to exclude the jurisdiction of the state court in the case from the dispute covered by the arbitration agreement.

2. A consequence of this assumption of the mixed nature of an arbitration agreement is that it is possible to determine which law will be applicable to the agreement. If an arbitration agreement is only a procedural concept, the admissibility, form and scope of the arbitration agreement will be governed only by the procedural law of the fori state, in accordance with the legis fori processualis principle.

3. The form of the arbitration agreement is therefore governed by the law applicable to the agreement. It seems that at present, a fairly liberal approach to formal requirements prevails and usually, in conventions, na- 
tional law (e.g. in the Polish Code of Civil Procedure) allows, apart from the written form, forms based on electronic communication, provided that the parties' declarations of intent are required to be preserved. This approach refers to the Polish document form contained in Art. 77 (2) of the Civil Code 